\title{
Peran Pupuk Organik dalam Peningkatan Efisiensi Pupuk Anorganik pada Padi Sawah (Oryza sativa L.)
}

\author{
The Role of Organic Fertilizer in Increasing Efficiency \\ of Inorganic Fertilizer on Paddy Rice (Oryza sativa L.)
}

\author{
Totong Siwanto ${ }^{1,2^{*}}$, Sugiyanta ${ }^{3}$, dan Maya Melati ${ }^{3}$ \\ ${ }^{1}$ Program Studi Agronomi dan Hortikultura, Sekolah Pascasarjana, Institut Pertanian Bogor \\ ${ }^{2}$ Badan Pelaksana Penyuluhan Pertanian Perikanan dan Kehutanan (BP4K), \\ Kabupaten Halmahera Timur, Provinsi Maluku Utara, Jl. Raya Soagimalaha, Kota Maba, Indonesia \\ ${ }^{3}$ Departemen Agronomi dan Hortikultura, Fakultas Pertanian, Institut Pertanian Bogor \\ (Bogor Agricultural University), Jl. Meranti, Kampus IPB Darmaga, Bogor 16680, Indonesia
}

Diterima 3 September 2014/Disetujui 6 Februari 2015

\begin{abstract}
Application of organic fertilizer into the soil is designated as a source of macro, micro nutrients and organic acids; it also acts as soil ameliorant that improve physical, chemical and biological properties of soil. Application of high rates organic fertilizer has a constraint namely the availability and ease of application. Therefore, it is necessary to learn the use of organic fertilizer with low rates to improve the efficiency of chemical fertilizers. This research was aimed to study the effect of organic and inorganic fertilizers on growth and yield of paddy rice, as well as the efficiency of $N, P$, $K$ inorganic fertilizer. Field experiment was conducted at Sawah Baru Research Station, University Farm IPB, Bogor, West Java from September to December 2013. The experiment used Randomized Block Design consisted of two factors: rates of organic fertilizer (0, 250, 500, 750, and 1,000 $\left.\mathrm{kg} \mathrm{ha}^{-1}\right)$, and rates of inorganic fertilizer (0, 100, 200, 300, and $\left.400 \mathrm{~kg} \mathrm{ha}^{-1}\right)$. The results suggested

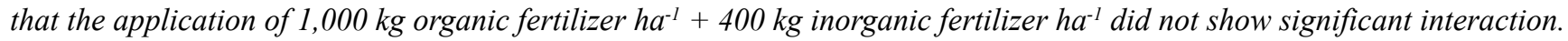
Application of organic fertilizer alone up to $1,000 \mathrm{~kg} \mathrm{ha}^{-1}$ resulted in low growth and yield. Increasing rates of application up to $400 \mathrm{~kg}$ inorganic fertilizer ha $\mathrm{a}^{-1}$ increased the growth and yield of paddy rice. The highest $N$ efficiency was $89.19 \%$ at a rate of $500 \mathrm{~kg}$ organic fertilizer ha $\mathrm{h}^{-1}+200 \mathrm{~kg}$ inorganic fertilizer $\mathrm{ha}^{-1}$, whereas the highest efficiency of P and K, respectively were $69.55 \%$ and $92.52 \%$ at a rate of $750 \mathrm{~kg}$ organic fertilizer $\mathrm{ha}^{-1}+300 \mathrm{~kg}_{\text {inorganic fertilizer ha-1. }}$.
\end{abstract}

Keywords: NPK, organic fertilizer, paddy rice

\section{ABSTRAK}

Aplikasi pupuk organik ke dalam tanah selain ditujukan sebagai sumber hara makro, mikro dan asam-asam organik, juga berperan sebagai bahan pembenah tanah untuk memperbaiki kesuburan fisik, kimia dan biologi tanah dalam jangka panjang. Aplikasi pupuk organik dengan dosis tinggi memiliki kendala yaitu ketersediaan dan kemudahan dalam aplikasi. Oleh karena itu, perlu dipelajari penggunaan pupuk organik dengan dosis yang rendah untuk meningkatkan efisiensi pemupukan anorganik. Penelitian ini bertujuan untuk mempelajari pengaruh pupuk organik dan anorganik terhadap pertumbuhan dan hasil padi sawah, serta terhadap efisiensi pemupukan N, P, Kanorganik. Percobaan dilaksanakan di Laboratorium Lapangan Riset Padi Babakan, Bogor, Jawa Barat pada bulan September sampai bulan Desember 2013. Percobaan ini menggunakan rancangan kelompok lengkap teracak (RKLT) terdiri atas dua faktor yaitu dosis pupuk organik terdiri atas 5 taraf yaitu 0, 250, 500, 750 dan 1,000 kg ha-1, dan dosis pupuk anorganik terdiri atas 5 taraf yaitu 0, 100, 200,300 dan $400 \mathrm{~kg} \mathrm{ha-1.}$

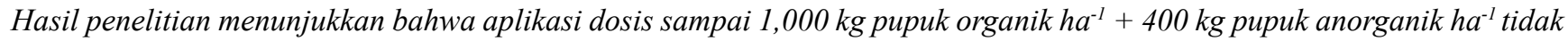
menunjukkan pengaruh interaksi nyata. Aplikasi dosis sampai 1,000 kg pupuk organik ha-1 saja menghasilkan pertumbuhan dan hasil yang rendah. Peningkatan aplikasi dosis sampai $400 \mathrm{~kg}$ pupuk anorganik ha-1 meningkatkan pertumbuhan dan hasil padi sawah. Efisiensi N tertinggi yaitu 89.19\% pada aplikasi dosis $500 \mathrm{~kg}$ pupuk organik ha-1 $+200 \mathrm{~kg}$ pupuk anorganik $\mathrm{ha}^{-1}$, sedangkan efisiensi $P$ dan $\mathrm{K}$ tertinggi yaitu masing-masing $69.55 \%$ dan $92.52 \%$ pada aplikasi dosis $750 \mathrm{~kg}$ pupuk organik ha $\mathrm{h}^{-1} 300 \mathrm{~kg}$ pupuk anorganik ha'.

Kata kunci: NPK, padi sawah, pupuk organik

\footnotetext{
* Penulis untuk korespondensi. e-mail: t.siswanto.ipb@gmail. com
} 


\section{PENDAHULUAN}

Revolusi hijau melahirkan varietas unggul berdaya hasil tinggi (high yielding varieties) yang responsif terhadap pemupukan. Pupuk anorganik menjadi komponen utama sarana produksi untuk mencapai produktivitas yang tinggi dan tidak mengaplikasikan bahan organik. Menurut Suriadikarta dan Simanungkalit (2006) dampak dari penggunaan pupuk anorganik secara intensif terlihat pada penurunan bahan organik tanah. Sugiyanta et al. (2008) menyatakan bahwa aplikasi pupuk anorganik berdosis tinggi dan tidak mengaplikasikan bahan organik menyebabkan kadar bahan organik tanah menjadi sangat rendah dan menjadi pembatas untuk mencapai hasil padi sawah yang tinggi.

Peraturan Menteri Pertanian Nomor: 40/2007 merekomendasikan pengembalian bahan organik atau pemberian pupuk organik yang dikombinasikan dengan pupuk anorganik dengan tujuan untuk memperbaiki kondisi dan kesuburan tanah (Badan Litbang Pertanian, 2010). Menurut Yang et al. (2004); Miyagawa (2005); Syukur (2005); Eugene et al. (2010); Leszczynska dan Malina (2011) aplikasi bahan organik sebagai pupuk organik dapat meningkatkan kadar hara, meningkatkan kemampuan kimiawi, meningkatkan kemampuan fisik dan meningkatkan aktivitas mikroba tanah. Kemudian Rochmah (2009); Widowati (2009) menyatakan bahwa aplikasi pupuk organik dapat memperbaiki sifat fisik, kimia dan meningkatkan efisiensi pemupukan.

Aplikasi pupuk organik bukan sebagai pengganti pupuk anorganik namun sebagai komplemen, sehingga dalam budidaya konvensional pupuk organik sebaiknya digunakan secara terpadu dengan pupuk anorganik untuk meningkatkan produktivitas tanah dan tanaman secara berkelanjutan. Aplikasi pupuk organik ke dalam tanah selain ditujukan sebagai sumber hara makro, mikro, dan asamasam organik, juga berperan sebagai bahan pembenah tanah (amelioran) untuk memperbaiki kesuburan fisik, kimia dan biologi tanah dalam jangka panjang.

Hasil penelitian Sugiyanta et al. (2008) menunjukkan bahwa penambahan $1 / 2$ dosis pupuk anorganik (125 kg urea $\mathrm{ha}^{-1}, 50 \mathrm{~kg} \mathrm{SP}-36 \mathrm{ha}^{-1}$ dan $50 \mathrm{~kg} \mathrm{KCl} \mathrm{ha}{ }^{-1}$ ) + aplikasi 7.5 ton jerami ha-1 menghasilkan serapan unsur hara dan hasil gabah yang sama dengan perlakuan pupuk anorganik dosis rekomendasi. Hasil tersebut menunjukkan bahwa aplikasi pupuk organik dapat mengefisienkan pupuk anorganik sekitar 50\%, walaupun sebenarnya sumbangan hara N, P, dan $\mathrm{K}$ dari pupuk organik relatif kecil sekitar $0-10 \%$ tergantung dari tingkat mineralisasi dari pupuk organik tersebut. Hal ini berarti $40 \%$ sampai $50 \%$ penyediaan hara N, P, dan K berasal dari perbaikan sifat fisik dan biologi tanah.

Aplikasi pupuk jerami dengan dosis tinggi memiliki kendala yaitu ketersediaan dan kemudahan dalam aplikasi. Oleh karena itu perlu dipelajari penggunaan pupuk organik sebagai komplementer dengan dosis yang rendah. Informasi mengenai jenis dan dosis pupuk organik + anorganik yang tepat akan bermanfaat dalam peningkatan efisiensi pemupukan $\mathrm{N}$, $\mathrm{P}$, dan $\mathrm{K}$ anorganik sehingga dapat meningkatkan pertumbuhan dan hasil padi sawah dengan optimal. Penelitian ini bertujuan untuk mempelajari pengaruh aplikasi dosis pupuk organik + anorganik terhadap pertumbuhan dan hasil padi sawah, serta terhadap efisiensi pemupukan $\mathrm{N}$, $\mathrm{P}$, dan $\mathrm{K}$ anorganik.

\section{BAHAN DAN METODE}

Percobaan dilaksanakan di Kebun Percobaan Sawah Baru, University Farm IPB, Bogor, Jawa Barat dengan ketinggian tempat $250 \mathrm{~m}$ dpl, pada bulan September sampai bulan Desember 2013. Analisis tanah, tanaman, dan pupuk dilakukan di Laboratorium Kimia dan Kesuburan Tanah Departemen Ilmu Tanah dan Sumberdaya Lahan (ITSL), Fakultas Pertanian Institut Pertanian Bogor. Bahan yang digunakan yaitu benih padi varietas Ciherang, pupuk organik (pupuk kandang sapi diperkaya mikroba), pupuk anorganik NPK (30:6:8). Alat-alat yang digunakan yaitu alat budidaya, timbangan digital, LI-COR 3000, bor tanah, dan oven.

Percobaan ini menggunakan rancangan kelompok lengkap teracak (RKLT) terdiri atas dua faktor yaitu dosis pupuk organik terdiri atas 5 taraf yaitu 0, 250, 500, 750, dan $1,000 \mathrm{~kg} \mathrm{ha}^{-1}$. Dosis pupuk anorganik terdiri atas 5 taraf yaitu $0,100,200,300$, dan $400 \mathrm{~kg} \mathrm{ha}^{-1}$. Jumlah total perlakuan adalah 25 kombinasi perlakuan, tiap perlakuan diulang tiga kali sehingga diperoleh 75 satuan percobaan. Satuan petak percobaan berukuran $5 \mathrm{~m}$ x $5 \mathrm{~m}$. Bibit dipindah tanam setelah berumur 15 hari setelah semai (HSS) dengan jumlah bibit 1 bibit per lubang tanam (tanam tunggal) dan dangkal 1-1.5 cm, jajar legowo 2:1 yaitu antar barisan 25 $\mathrm{cm}$, dalam barisan $12.5 \mathrm{~cm}$ dan antar legowo $50 \mathrm{~cm}$. Pupuk organik diberikan 1 minggu sebelum tanam sedangkan pupuk anorganik diberikan dua kali, yaitu $60 \%$ pada 5 hari setelah tanam (HST) dan $40 \%$ pada $35 \mathrm{HST}$.

Peubah pengamatan pertumbuhan antara lain tinggi tanaman, jumlah anakan, luas daun dan efisiensi pemupukan. Peubah pertumbuhan tersebut diamati pada 4, 6, dan 8 minggu setelah tanam (MST). Perhitungan efisiensi pemupukan dilakukan berdasarkan kadar unsur hara dan penyerapan tanaman masing-masing perlakuan terhadap besarnya aplikasi dosis pupuk. Peubah komponen hasil dan hasil antara lain anakan produktif, panjang malai, jumlah gabah per malai, bobot 1,000 butir gabah, gabah kering panen (GKP) dan gabah kering giling (GKG). Analisis data menggunakan sidik ragam, apabila dalam sidik ragam pada taraf 5\% terdapat pengaruh nyata maka dilanjutkan dengan uji DMRT (Duncan Multiple Range Test).

\section{HASIL DAN PEMBAHASAN}

\section{Pertumbuhan Padi}

Secara umum tidak terdapat pengaruh interaksi yang nyata antara aplikasi dosis pupuk organik dan anorganik terhadap peubah pertumbuhan dan hasil padi. Aplikasi dosis sampai $1,000 \mathrm{~kg}$ pupuk organik ha-1 saja tidak berpengaruh nyata terhadap peubah pertumbuhan dan hasil padi (Tabel $1,2,3$, dan 4). Rendahnya pertumbuhan dan hasil padi yang 
tidak nyata antar dosis disebabkan perbedaan dosis yang relatif kecil untuk pupuk organik. Ada beberapa kelemahan pupuk organik yaitu: (1) kandungan hara pupuk organik rendah sehingga tanpa pupuk anorganik menyebabkan sumbangan hara sangat sedikit, (2) pupuk organik harus melalui proses mineralisasi, dan (3) immobilisasi unsur hara sehingga unsur hara lambat tersedia bagi tanaman. Menurut Suriadikarta dan Simanungkalit (2006) pupuk organik memiliki fungsi kimia yang penting yaitu penyediaan unsur hara makro dan mikro tetapi dalam jumlah yang sedikit, sehingga berbagai hasil penelitian pupuk organik menunjukkan pengaruh yang tidak berbeda. Kemudian menurut Chairani (2006) selain karena rendahnya kadar unsur hara dalam pupuk organik, unsur hara pada pupuk organik harus melalui proses mineralisasi terlebih dahulu sehingga lambat tersedia bagi tanaman.

Selain rendahnya kandungan unsur hara dan proses mineralisasi pupuk organik, dugaan lain yaitu terjadinya proses immobilisasi unsur hara. Hasil penelitian Sugiyanta et al. (2008) menunjukkan bahwa kondisi rendahnya pertumbuhan, komponen hasil, dan hasil padi pada perlakuan jerami saja hingga musim tanam-2 (MT-2) dan tidak berbeda

Tabel 1. Pengaruh pupuk organik dan anorganik terhadap tinggi tanaman dan jumlah anakan

\begin{tabular}{|c|c|c|c|c|c|c|}
\hline \multirow{3}{*}{ Perlakuan } & \multicolumn{6}{|c|}{ Pengamatan } \\
\hline & \multicolumn{3}{|c|}{ Tinggi tanaman $(\mathrm{cm})$} & \multicolumn{3}{|c|}{ Jumlah anakan } \\
\hline & $4 \mathrm{MST}$ & $6 \mathrm{MST}$ & $8 \mathrm{MST}$ & $4 \mathrm{MST}$ & $6 \mathrm{MST}$ & $8 \mathrm{MST}$ \\
\hline \multicolumn{7}{|c|}{ Pupuk organik $\left(\mathrm{kg} \mathrm{ha}^{-1}\right)$} \\
\hline 0 & 42.28 & 56.83 & 70.91 & 12.1 & 18.6 & 23.4 \\
\hline 250 & 43.44 & 59.79 & 74.75 & 11.6 & 19.1 & 22.7 \\
\hline 500 & 44.66 & 59.76 & 74.76 & 13.1 & 20.3 & 24.7 \\
\hline 750 & 42.26 & 57.67 & 72.17 & 10.8 & 18.5 & 23.6 \\
\hline 1,000 & 42.04 & 58.56 & 73.31 & 12.0 & 19.0 & 24.7 \\
\hline \multicolumn{7}{|c|}{ Pupuk anorganik (kg ha-1) } \\
\hline 0 & 42.00 & $55.59 \mathrm{c}$ & $65.71 \mathrm{c}$ & 10.0 & $14.9 \mathrm{c}$ & $17.3 \mathrm{~d}$ \\
\hline 100 & 41.72 & $56.40 \mathrm{c}$ & $68.39 \mathrm{c}$ & 11.1 & $17.3 b$ & $21.0 \mathrm{c}$ \\
\hline 200 & 43.65 & $58.33 b c$ & $74.04 \mathrm{~b}$ & 12.5 & $20.6 \mathrm{a}$ & $25.2 \mathrm{~b}$ \\
\hline 300 & 44.13 & $60.68 \mathrm{ab}$ & $78.04 \mathrm{a}$ & 13.5 & $21.1 \mathrm{a}$ & $27.2 \mathrm{ab}$ \\
\hline 400 & 43.18 & $61.60 \mathrm{a}$ & $79.72 \mathrm{a}$ & 12.5 & $21.6 \mathrm{a}$ & $28.3 \mathrm{a}$ \\
\hline
\end{tabular}

Keterangan: Angka-angka yang diikuti huruf yang sama pada kolom yang sama tidak berbeda nyata berdasarkan uji Duncan pada $\alpha=5 \%$. MST = minggu setelah tanam

Tabel 2. Pengaruh pupuk organik dan anorganik terhadap luas daun

\begin{tabular}{|c|c|c|c|}
\hline \multirow{2}{*}{ Perlakuan } & \multicolumn{3}{|c|}{ Luas daun $\left(\mathrm{cm}^{2}\right)$} \\
\hline & $4 \mathrm{MST}$ & $6 \mathrm{MST}$ & $8 \mathrm{MST}$ \\
\hline \multicolumn{4}{|c|}{ Pupuk organik $\left(\mathrm{kg} \mathrm{ha}^{-1}\right)$} \\
\hline 0 & 313.74 & 738.12 & 1051.13 \\
\hline 250 & 334.05 & 740.31 & 1101.95 \\
\hline 500 & 364.81 & 751.49 & 1075.80 \\
\hline 750 & 299.26 & 679.78 & 1044.67 \\
\hline 1,000 & 319.40 & 645.41 & 1035.17 \\
\hline \multicolumn{4}{|c|}{ Pupuk anorganik (kg ha $\left.{ }^{-1}\right)$} \\
\hline 0 & 272.07 & $507.00 \mathrm{c}$ & $764.03 b$ \\
\hline 100 & 307.52 & $663.63 b$ & $886.16 b$ \\
\hline 200 & 335.43 & $791.96 \mathrm{a}$ & $1182.44 \mathrm{a}$ \\
\hline 300 & 349.00 & $765.70 \mathrm{ab}$ & $1230.36 \mathrm{a}$ \\
\hline 400 & 367.25 & $826.83 a$ & $1245.75 \mathrm{a}$ \\
\hline
\end{tabular}

Keterangan: Angka-angka yang diikuti huruf yang sama pada kolom yang sama tidak berbeda nyata berdasarkan uji Duncan pada $\alpha=5 \%$ $\mathrm{MST}=$ minggu setelah tanam 
pada MT-3 karena adanya pengaruh imobilisasi $\mathrm{N}$ dan $\mathrm{P}$ oleh jerami selama dua musim tanam pertama, walaupun demikian pada MT-3 sudah terlihat adanya mineralisasi unsur $\mathrm{N}$ sehingga serapan dan $\mathrm{N}$ tanah tersedia mulai meningkat. Hal ini menunjukkan bahwa aplikasi pupuk organik saja tanpa penambahan pupuk anorganik akan menyebabkan imobilisasi unsur hara sehingga unsur hara tersebut tersedia secara perlahan-lahan bagi tanaman.

Hasil analisis statistik menunjukkan bahwa aplikasi pupuk anorganik berpengaruh nyata pada 6 MST dan 8 MST terhadap peubah tinggi tanaman, jumlah anakan dan luas daun. Aplikasi dosis $400 \mathrm{~kg}$ pupuk anorganik ha-1 tidak nyata meningkatkan tinggi tanaman dan jumlah anakan dibandingkan dengan aplikasi dosis $300 \mathrm{~kg}$ pupuk anorganik ha $^{-1}$ (Tabel 1), dan tidak nyata meningkatkan luas daun dibandingkan dengan aplikasi dosis 200 dan $300 \mathrm{~kg}$ pupuk anorganik ha-1 (Tabel 2). Peningkatan aplikasi dosis pupuk anorganik menunjukkan peningkatan ketersediaan unsur hara terutama nitrogen $(\mathrm{N})$ dalam tanah. Unsur hara yang terkandung dalam pupuk anorganik lebih cepat tersedia bagi tanaman. Unsur $\mathrm{N}$ merupakan unsur yang sangat penting pada fase vegetatif tanaman, serta merupakan unsur hara yang paling menjadi faktor penghambat pertumbuhan dan hasil padi sawah. Bertambahnya luas daun per rumpun pada tahap anakan aktif dan anakan maksimum diduga karena meningkatnyajumlah anakan per rumpun. Menurut Rachman

Tabel 3. Pengaruh pupuk organik dan anorganik terhadap komponen hasil

\begin{tabular}{|c|c|c|c|c|}
\hline Perlakuan & $\begin{array}{c}\text { Jumlah anakan } \\
\text { produktif }\end{array}$ & $\begin{array}{l}\text { Panjang malai } \\
(\mathrm{cm})\end{array}$ & $\begin{array}{c}\text { Jumlah gabah } \\
\text { per malai }\end{array}$ & $\begin{array}{c}\text { Bobot } 1,000 \text { butir gabah } \\
(\mathrm{g})\end{array}$ \\
\hline \multicolumn{5}{|c|}{ Pupuk organik $\left(\mathrm{kg} \mathrm{ha}^{-1}\right)$} \\
\hline 0 & 13.9 & 22.98 & 140.9 & 26.12 \\
\hline 250 & 14.7 & 22.93 & 135.1 & 26.84 \\
\hline 500 & 14.6 & 22.82 & 134.8 & 26.80 \\
\hline 750 & 13.8 & 22.89 & 136.5 & 26.71 \\
\hline 1,000 & 13.8 & 22.72 & 139.6 & 26.12 \\
\hline \multicolumn{5}{|c|}{ Pupuk anorganik (kg ha $\left.{ }^{-1}\right)$} \\
\hline 0 & $11.9 \mathrm{c}$ & $22.30 \mathrm{c}$ & $126.2 \mathrm{c}$ & 26.12 \\
\hline 100 & $12.5 \mathrm{c}$ & $22.63 b c$ & $127.4 \mathrm{c}$ & 25.93 \\
\hline 200 & $14.9 \mathrm{~b}$ & $22.78 \mathrm{abc}$ & $137.5 b c$ & 27.24 \\
\hline 300 & $15.3 \mathrm{ab}$ & $23.24 \mathrm{ab}$ & $145.4 \mathrm{ab}$ & 26.60 \\
\hline 400 & $16.2 \mathrm{a}$ & $23.39 \mathrm{a}$ & $150.4 \mathrm{a}$ & 26.99 \\
\hline
\end{tabular}

Keterangan: Angka-angka yang diikuti huruf yang sama pada kolom yang sama tidak berbeda nyata berdasarkan uji Duncan pada $\alpha=5 \%$

Tabel 4. Pengaruh pupuk organik dan anorganik terhadap hasil

\begin{tabular}{|c|c|c|c|c|}
\hline \multirow{2}{*}{ Perlakuan } & \multicolumn{2}{|c|}{ Bobot gabah (g per rumpun) } & \multicolumn{2}{|c|}{ Bobot gabah (ton ha $\left.{ }^{-1}\right)$} \\
\hline & GKP & GKG & GKP & GKG \\
\hline \multicolumn{5}{|c|}{ Pupuk organik $\left(\mathrm{kg} \mathrm{ha}^{-1}\right)$} \\
\hline 0 & 21.75 & 15.97 & 5.80 & 4.25 \\
\hline 250 & 21.58 & 16.96 & 5.75 & 4.52 \\
\hline 500 & 22.75 & 16.71 & 6.06 & 4.45 \\
\hline 750 & 21.29 & 16.25 & 5.68 & 4.33 \\
\hline 1,000 & 21.33 & 16.17 & 5.69 & 4.31 \\
\hline \multicolumn{5}{|c|}{ Pupuk anorganik ( $\left.\mathrm{kg} \mathrm{ha}^{-1}\right)$} \\
\hline 0 & $16.50 \mathrm{c}$ & $12.21 \mathrm{c}$ & $4.40 \mathrm{c}$ & $3.25 \mathrm{c}$ \\
\hline 100 & $18.13 \mathrm{c}$ & $13.31 \mathrm{c}$ & $4.83 \mathrm{c}$ & $3.55 \mathrm{c}$ \\
\hline 200 & $22.25 b$ & $17.25 b$ & $5.93 b$ & $4.60 \mathrm{~b}$ \\
\hline 300 & $24.95 \mathrm{a}$ & $18.88 \mathrm{ab}$ & $6.65 \mathrm{a}$ & $5.03 \mathrm{ab}$ \\
\hline 400 & $26.88 \mathrm{a}$ & $20.42 \mathrm{a}$ & $7.16 \mathrm{a}$ & $5.44 \mathrm{a}$ \\
\hline
\end{tabular}

Keterangan: Angka-angka yang diikuti huruf yang sama pada kolom yang sama tidak berbeda nyata berdasarkan uji Duncan pada $\alpha=5 \%$. $\mathrm{GKP}=$ gabah kering panen, $\mathrm{GKG}=$ gabah kering giling 
et al. (2008) dan Rubio et al. (2009), $\mathrm{N}$ berperan dalam memacu pertumbuhan vegetatif tanaman dan meningkatkan kualitas daun. Hasil penelitian tersebut sejalan dengan hasil penelitian Wahyuti (2011) yang menunjukkan bahwa peningkatan tinggi tanaman dan pembentukan anakan padi sawah varietas Ciherang, Maro, dan galur B11143 dipengaruhi oleh meningkatnya aplikasi dosis pupuk $\mathrm{N}$. Varietas Maro dan Ciherang mempunyai kemampuan membentuk anakan lebih banyak sehingga memiliki luas daun lebih besar.

\section{Komponen Hasil dan Hasil Padi}

Tabel 3 dan 4 menunjukkan pola yang sama bahwa aplikasi dosis $400 \mathrm{~kg}$ pupuk anorganik ha $\mathrm{h}^{-1}$ menghasilkan komponen hasil (jumlah anakan produktif, panjang malai, jumlah gabah per malai) dan hasil (gabah kering panen dan gabah kering giling) lebih tinggi dibandingkan dengan perlakuan tanpa pemupukan, aplikasi dosis $100 \mathrm{~kg}$ pupuk anorganik ha-1 dan $200 \mathrm{~kg}$ pupuk anorganik ha-1, akan tetapi tidak menunjukkan perbedaan yang nyata dengan aplikasi dosis $300 \mathrm{~kg}$ pupuk anorganik ha-1. Hasil analisis regresi hubungan pupuk anorganik dengan hasil (ton $\mathrm{ha}^{-1}$ ) menunjukkan pola linier, sehingga peningkatan aplikasi dosis pupuk anorganik yang semakin tinggi dapat meningkatkan hasil yang lebih tinggi (Gambar 1).

Peningkatan aplikasi dosis sampai $400 \mathrm{~kg}$ pupuk anorganik ha ${ }^{-1}$ akan meningkatkan ketersediaan unsur hara terutama N, P, dan K tanah. Komponen hasil dan hasil gabah dipengaruhi oleh fotosintesis tanaman, dimana proses ini dipengaruhi oleh unsur hara N, P, dan $\mathrm{K}$. Unsur N berfungsi meningkatkan kandungan klorofil daun tanaman sehingga proses fotosisntesis tanaman meningkat. Jumlah klorofil yang tinggi menunjukkan proses fotosintesis dapat berjalan dengan baik (Suharno et al., 2007; Ai dan Banyo, 2011). Hasil penelitian Dong et al. (2009); Zhang et al. (2011) menunjukkan bahwa pemberian N $60 \%$ pada tahap awal dan $40 \%$ tahap akhir menyebabkan meningkatnya ketersediaan $\mathrm{N}$ pada tahap pertumbuhan akhir yang dapat mempengaruhi metabolisme daun selama pengisian biji. Unsur P berperan dalam suplai dan transfer energi seluruh proses biokimia padi, salah satunya yaitu mempercepat pemasakan dan

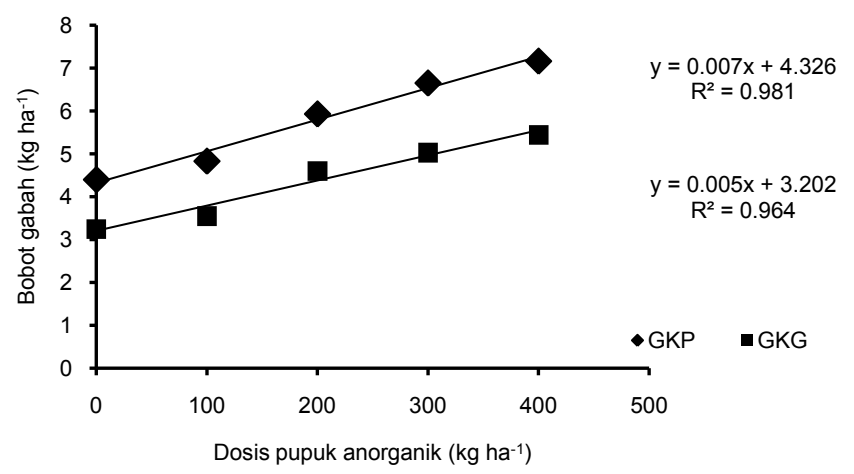

Gambar 1. Hubungan dosis pupuk anorganik dengan GKP dan GKG (ton ha $\left.{ }^{-1}\right)$ perkembangan gabah sehingga bobot gabah meningkat. Unsur K berfungsi untuk pembentukan gula, zat tepung dan berbagai macam enzim sehingga jumlah gabah per malai dan persen gabah isi dapat ditingkatkan (Booromand dan Grough, 2012).

\section{Efisiensi Pemupukan}

Aplikasi dosis pupuk organik + dosis pupuk anorganik dapat meningkatkan efisiensi pemupukan. Hasil tersebut dapat terlihat pada aplikasi dosis $500 \mathrm{~kg}$ pupuk organik $\mathrm{ha}^{-1}+200 \mathrm{~kg}$ pupuk anorganik ha-1 menghasilkan efisiensi pemupukan $\mathrm{N}$ tertinggi sampai $89.19 \%$, sedangkan aplikasi dosis $750 \mathrm{~kg}$ pupuk organik $\mathrm{ha}^{-1}+300 \mathrm{~kg}$ pupuk anorganik ha-1 menghasilkan efisiensi pemupukan $\mathrm{P}$ dan $\mathrm{K}$ tertinggi masing-masing yaitu $69.55 \%$ dan $92.52 \%$ (Tabel 5) dibandingkan dengan perlakuan lainnya. Peningkatan efisiensi pemupukan ini dipengaruhi oleh peran pupuk organik dalam meningkatkan ketersediaan hara bagi tanaman serta peningkatan aktivitas dan keanekaragaman hayati biota tanah.

Proses kimia yang disebabkan oleh penggenangan tanah sawah sangat mempengaruhi dinamika aktivitas mikroba dan ketersediaan hara tanaman. Pada kondisi jenuh air (anaerob) tanah sulit mendapatkan $\mathrm{O}_{2}$ sehingga mengganggu aktivitas mikroba dalam tanah. Azospirillum sp, Azotobacter, dan bakteri pelarut fosfat adalah mikroba yang hidup di daerah rizosfer tanaman dan merupakan bakteri aerob obligatif atau bakteri yang memerlukan oksigen bebas sehingga peran oksigen menjadi salah satu faktor dalam perkembangan hidupnya. Metode SRI (System Rice of Intensification) mengkondisikan lahan dalam keadaan yang tidak selalu tergenang (intermitten), sehingga memungkinkan pada bagian rizosfer dalam keadaan oksidatif. Hal ini mendorong Azospirillum sp, Azotobacter, dan mikroorganisme aerob lainnya dapat berkembang dengan baik. Lerner (2005); Ponmurugan dan Gopi (2006); Mehrvarz et al. (2008) menyatakan bahwa peningkatan aktivitas dan populasi mikroba tergantung dari jenis tanaman, bahan organik, dan teknik budidaya. Hasil penelitian Bakrie (2011) menunjukkan bahwa aplikasi pupuk anorganik + organik hayati dengan metode SRI dapat meningkatkan aktivitas dan jumlah populasi mikroba (Azotobacter dan mikroba pelarut fosfat).

Selain itu, penambahan bahan organik tanah akan berfungsi sebagai penyangga (buffer) $\mathrm{pH}$ tanah, meningkatkan ketersediaan $\mathrm{N}$ dan $\mathrm{C}$ tanah, serta menekan nematoda dan senyawa beracun. Sugiyanta et al. (2008) menyatakan bahwa bahan organik tanah mempunyai peran sangat penting karena sebagai kunci mekanistik untuk suplai unsur hara, dengan biomas mikrobial yang segmen siklusnya sangat cepat, fase organik bertindak sebagai biokatalis untuk suplai unsur hara dan pool hara itu sendiri. Hasil penelitian Sugiyanta et al. (2008) menunjukkan bahwa aplikasi pupuk organik + anorganik berpengaruh terhadap peningkatan kadar unsur hara $\mathrm{P}$ dan $\mathrm{K}$ tanah dibandingkan dengan aplikasi pupuk anorganik saja. 
Tabel 5. Pengaruh aplikasi dosis pupuk organik dan anorganik terhadap efisiensi pemupukan N, P dan K padi sawah

\begin{tabular}{|c|c|c|c|c|c|c|}
\hline \multirow{2}{*}{ Perlakuan } & \multicolumn{5}{|c|}{ Pupuk anorganik (kg ha $\left.{ }^{-1}\right)$} & \multirow{2}{*}{$\begin{array}{c}\text { Rataan } \\
\text { pupuk organik }\end{array}$} \\
\hline & 0 & 100 & 200 & 300 & 400 & \\
\hline \multicolumn{7}{|c|}{ Efisiensi pemupukan N (\%) } \\
\hline \multicolumn{7}{|l|}{ Pupuk organik $\left(\mathrm{kg} \mathrm{ha}^{-1}\right)$} \\
\hline 0 & - & 72.07 & 69.66 & 57.80 & 65.18 & 66.18 \\
\hline 250 & 57.23 & 73.72 & 76.46 & 68.52 & 72.16 & 69.62 \\
\hline 500 & 72.64 & 72.08 & 68.67 & 89.19 & 71.48 & 74.81 \\
\hline 750 & 72.49 & 74.02 & 84.52 & 86.40 & 75.03 & 78.49 \\
\hline 1,000 & 58.00 & 84.43 & 77.17 & 77.90 & 73.85 & 74.27 \\
\hline \multirow[t]{2}{*}{ Rataan pupuk anorganik } & 65.09 & 75.26 & 75.30 & 75.96 & 71.54 & 72.67 \\
\hline & \multicolumn{6}{|c|}{ Efisiensi pemupukan $\mathrm{P}(\%)$} \\
\hline \multicolumn{7}{|l|}{ Pupuk organik (kg ha-1) } \\
\hline 0 & - & 41.81 & 49.79 & 58.18 & 46.62 & 49.10 \\
\hline 250 & 46.30 & 59.67 & 64.48 & 68.34 & 64.59 & 60.68 \\
\hline 500 & 62.35 & 49.45 & 60.73 & 69.41 & 63.10 & 61.01 \\
\hline 750 & 49.51 & 42.79 & 61.65 & 69.55 & 63.78 & 57.46 \\
\hline 1,000 & 64.06 & 55.54 & 58.72 & 61.55 & 68.69 & 61.77 \\
\hline \multirow[t]{2}{*}{ Rataan pupuk anorganik } & 55.56 & 49.85 & 59.07 & 5.41 & 61.41 & 58.00 \\
\hline & \multicolumn{6}{|c|}{ Efisiensi pemupukan K (\%) } \\
\hline \multicolumn{7}{|l|}{ Pupuk organik (kg ha-1) } \\
\hline 0 & - & 80.33 & 75.87 & 85.84 & 78.83 & 80.22 \\
\hline 250 & 81.05 & 75.91 & 92.03 & 87.56 & 86.81 & 84.67 \\
\hline 500 & 88.90 & 85.19 & 81.90 & 76.32 & 86.65 & 83.79 \\
\hline 750 & 60.59 & 58.78 & 86.27 & 92.52 & 91.00 & 77.36 \\
\hline 1,000 & 64.31 & 66.23 & 72.87 & 77.63 & 75.77 & 71.36 \\
\hline Rataan pupuk anorganik & 73.72 & 73.29 & 81.79 & 83.97 & 83.31 & 79.58 \\
\hline
\end{tabular}

Keterangan: Nilai tidak dianalisis statistik

\section{KESIMPULAN}

Interaksi nyata antara pupuk organik dan anorganik tidak berpengaruh nyata terhadap semua peubah yang diamati. Aplikasi pupuk organik sampai dosis $1,000 \mathrm{~kg}$ ha $^{-1}$ tidak meningkatkan pertumbuhan dan hasil padi, sebaliknya aplikasi pupuk anorganik sampai dosis 400 $\mathrm{kg} \mathrm{ha}^{-1}$ meningkatkan pertumbuhan dan hasil padi. Aplikasi pupuk organik dapat meningkatkan efisiensi pemupukan anorganik. Efisiensi $\mathrm{N}$ tertinggi (89.19\%) pada aplikasi dosis $500 \mathrm{~kg}$ pupuk organik ha ${ }^{-1}+300 \mathrm{~kg}$ pupuk anorganik $\mathrm{ha}^{-1}$, dan efisiensi $\mathrm{P}$ dan $\mathrm{K}$ tertinggi (69.55\% dan 92.52\%) pada aplikasi dosis $750 \mathrm{~kg}$ pupuk organik ha-1 $+300 \mathrm{~kg}$ pupuk anorganik $\mathrm{ha}^{-1}$. Aplikasi pupuk anorganik pada padi sawah cukup $300 \mathrm{~kg} \mathrm{ha}^{-1}$ apabila ditambah dengan 500 $\mathrm{kg} \mathrm{ha}^{-1}$ pupuk organik.

\section{DAFTAR PUSTAKA}

Ai, N.S., Y. Banyo. 2011. Konsentrasi klorofil daun sebagai indikator kekurangan air pada tanaman. J. Ilmiah Sains. 11:166-173.
[Badan Litbang] Badan Penelitian dan Pengembangan Pertanian. 2010. Peta potensi penghematan pupuk anorganik dan pengembangan pupuk organik pada lahan sawah Indonesia. Kementerian Pertanian. Jakarta.

Bakrie, M.M. 2011. Aplikasi pupuk anorganik dan pupuk organik hayati pada budidaya padi SRI (System Rice of Intensification). Tesis. Sekolah Pascasarjana. Institut Pertanian Bogor. Bogor.

Booromand, N., M.S.H. Grough. 2012. Macroelements nutrition (NPK) of medicinal plants. J. Med. Plants Res. 6:2249-2255.

Chairani. 2006. Pengaruh fosfor dan pupuk kandang kotoran sapi terhadap sifat kimia tanah dan pertumbuhan tanaman padi (Oryza sativa L) pada lahan sawah tadah hujan di Kabupaten Langkat, Sumatra Utara. J. Penelitian Pertanian Indonesia 25:8-17. 
Dong, G.C., Y.L. Wang, Z. Juan, Z. Biao, C.S. Zhang, Y.F. Zhang, L.X. Yang, J.Y. Huang. 2009. Characteristics of nitrogen distribution and translocation in conventional indica rice varieties with different nitrogen use efficiency for grain output. Acta Agron. Sin. 35:149-155.

Eugene, E.E., E. Jacques, V.T. Desire, B. Paul. 2010. Effects of some physical and chemical characteristic of soil on productivity and yield of cowpea (Vigna unguiculata L. Walp.) in Coastal Region(Cameroon). Afr. J. Environ. Sci. Technol. 4:108-114.

Lerner, A. 2005. Effects of Azospirillum inoculation on rhizobacterial communities analized by denaturing gel electrophoresis and automated ribosomal intergenic spacer analysis. Soil Bio. Biochem. 20:1-7.

Leszczynska. D., J.K. Malina. 2011. Effect of organic matter from various sources on yield and quality of plant on soils contaminated with heavy metals. J. Ecol. Chem. Enginering. 18:501-507.

Mehrvarz, S., M.R. Chaichi, H.A. Alikhani. 2008. Effect of phosphate solubilizing microorganism and phosphorus chemical fertilizer on yield and yield components of barley (Hordeum vulgare L.). J. Agric. Environ. Sci. 3:822-828.

Miyagawa, K. 2005. Current chicken manure treatment facility in Japan. p. 249-261. CHIMATRA-Chicken Manure Treatment and Application, Proceedings of the International Workshop. Hamburg, Germany. Verlag Abfall 19-20 January 2005.

Ponmurugan, P., C. Gopi. 2006. Distribution pattern and screening of phosphate solubilizing bacteria isolated from different food and forage crops. J. Agronomy. 5:600-604.

Rachman, I.A., S. Djuniwati, K. Idris. 2008. Pengaruh bahan organik dan pupuk NPK terhadap serapan hara produksi jagung di Inceptisol Ternate. J. Tanah dan Lingkungan. 10:7-13.

Rochmah, H.F. 2009. Pengaruh pupuk organik dan anorganik terhadap pertumbuhan dan hasil padi sawah (Oryza sativa L.). Skripsi. Institut Pertanian Bogor. Bogor.
Rubio, V., R. Bustos, M.L. Irigoyen, L.X. Cardona, T.M. Rojas, A.J. Paz. 2009. Plant hormones and nutrient signaling. Plant Mol. Biol. 69:361-373.

Sugiyanta, F. Rumawas, M.A. Chozin, W.Q. Mugnisyah, M. Ghulamahdi. 2008. Studi serapan hara N, P, K, dan potensi hasil lima varietas padi sawah (Oryza sativa L.) pada pemupukan anorganik dan organik. Bul. Agron. 36:196-203.

Suharno, I. Mawardi, Setiabudi, N. Lunga, S. Tjitrosemito. 2007. Efisiensi penggunaan nitrogen pada tipe vegetasi yang berbeda di stasiun penelitian Taman Nasional Gunung Halimun Jawa Barat. Biodiversitas $8: 287-294$.

Suriadikarta, D.A., R.D.M. Simanungkalit. 2006. Pupuk organik dan pupuk hayati. J. Litbang Pertanian. 26:110.

Syukur, A. 2005. Pengaruh pemberian bahan organik terhadap sifat-sifat tanah dan pertumbuhan caisim di tanah pasir pantai. J. Ilmu Tanah dan Lingkungan 5:30-38.

Wahyuti, T.B. 2011. Pengaruh pengelolaan hara nirogen terhadap hasil padi varietas unggul. Disertasi. Sekolah Pascasarjana. Institut Pertanian Bogor. Bogor.

Widowati, L.R. 2009. Peranan pupuk organik terhadap efisiensi pemupukan dan tingkat kebutuhannya untuk tanaman sayuran pada tanah Inseptisols Ciherang. J. Tanah Tropika. 14:221-228.

Yang, S.M., P. Mahli, D.R. Wang, J.G. Wang. 2004. Longterm fertilization effect on crop yield and nitrate nitrogen accumulation of organic matter and fertilizers on crop yield and nitrate- $\mathrm{N}$ accumulation in soil in Northwestern China. J. Agron. 96:1039-1049.

Zhang, J.H., J.L. Liu, J.B. Zhang, F.T. Zhao, Y.N. Cheng, W.P. Wang. 2010. Effects of nitrogen aplication rates on translocation of dry matter and nitrogen utilization in rice and wheat. Acta Agron. Sin. 36:1736-1742. 